\title{
THE INFLUENCE OF ICE BREAKER TO STUDENTS' MOTIVATION IN TEACHING ENGLISH
}

\author{
Ayu Rindu Astuti ${ }^{1}$, Asti Solihat ${ }^{2}$, Intan Satriani ${ }^{3}$ \\ ${ }^{1}$ IKIP Siliwangi \\ ${ }^{2}$ IKIP Siliwangi \\ ${ }^{3}$ IKIP Siliwangi \\ ${ }^{1}$ ayurinduastuti@gmail.com, ${ }^{2}$ astisolihat5@gmail.com, ${ }^{3}$ intan.satriani@yahoo.co.id
}

\begin{abstract}
This research is aimed at exploring ice breaker technique in teaching English for student at Junior High School in Cimahi. Based on the important of teaching English in Indonesia as foreign language. So by doing ice breaking before learning, it is expected that students can focus on the learning English process. In this research the writer used case study and qualitative research method. The subject of this research was on of an English teacher at One of Junior High School in Cimahi. The instrument of this research are observation, and interview. The result of this research is students' to be focus and fun on learning English in the class.
\end{abstract}

Keywords: Teaching English, Ice Breaking, Motivation of learning

\section{INTRODUCTION}

Learning activity is an activity that must be followed by all students and teachers, with the aim of achieve the success of educational goals. The success of learning depends on an effective learning process in the classroom. According to Dollard and Miller (1981: 148) in Dollard, Dollard, \& Miller, n.d. books the effectiveness of learning behavior is influenced by 4 things, namely the existence of motivation, attention and knowing the goals, efforts, and evaluation of the use of results.

Based on Bornstein (1987), Budiawan (2008), motivation is a form of encourage from the inside (inner drive), and also encouragement that can move a person to do certain activities. Therefore motivation to learn English is influenced by many things, one of which is a learning process that is not conducive and does not vary. So that the learning process becomes bored and decreases the motivation of students to improve their English skills.

The teacher is a student guide in classroom learning activities that must be able to manage the learning process to be effective. Effective learning according to the curriculum is divided into three parts, namely the introduction, core, and closing sections. Usually in the preliminary activities the teacher only greets and checks the attendance of the student then progresses to the core activities. In this case many students are not ready to accept the material provided by the teacher, thus reducing students' motivation and interest in capturing a learning material.

\section{Teaching English}

Studying languages has been done by humans since birth, starting from the mother tongue. Language has central role on intellectual development, social, and emotional students to supported success student and learn all of lessons, Parmawati (2018). But in the current era of globalization, learning foreign languages such as English is very necessary. Like the opinion 
expressed by Nunan (2005) in Yeganehpour \& Takkaç, (2016) namely the ability to use a second language or foreign language will develop automatically if the learner is directed to focus in communication. The second language referred to in the opinion is a foreign language that is generally studied by students at school.

Second language is a language that is very necessary when formal, social, trade or education activities. While foreign languages are languages used by people to communicate with other people who are not from their country.

So from that it can be concluded that learning foreign languages such as English at school is considered important and must be mastered by the Indonesian Nation because English as a communication tool is also a language of association between nations. In addition, English is also the first foreign language that is considered important for the purpose of adding information and developing science, technology, and cultural arts.

\section{Motivation}

According to Mc. Donald quoted by Sardiman (2003) in Dauyah, Abulyatama, \& Besar (2018) motivation is a change in energy in a person who is marked with the emergence of "feeling" and preceded by a response to purpose. From the understanding expressed by Mc.Donald contains three important elements, namely, (1) that motivation initiates changes in energy in each individual humans, (2) motivation is characterized by the emergence of feeling and affection someone, (3) motivation will be stimulated because of the purpose.

From some of these opinions it can be concluded that motivation is something that causes a change in oneself individuals who influence psychiatric symptoms, feelings, and emotions to do something that is driven by purpose, needs or desire.

\section{Ice Breaking}

The term ice breaker comes from two foreign words, namely ice which means ice has a rigid, cold, and hard nature, while the breaker means solving. Meaning literally an ice-breaker is an "ice breaker". So, an ice breaker can be interpreted as attempts to break or melt the atmosphere that is rigid as ice to become more comfortable flowing and relaxing.

Ice breaking is an activity that can be used to solve the tension and saturation of students in learning, so that the class becomes fun and more conducive before entering into core activities. The conducive situation will be more effective to help students achieve learning goals compared to a tense situation. Ice breaking can do in various activity, such as game, short story, and guessing.this activity done in time 5 until 15 minutes.

There are several benefits of doing ice breaking activities, including the ones eliminate boredom, boredom, anxiety, and fatigue because they can get out while from the routine of the lesson by doing free and cheerful activities, also other benefits such as: Train creative thinking and broad students, Develop and optimize the brain and creativity of students, Train students to interact in groups and work together in a team, Train systematic and creative thinking to solve problems, Increase self-confidence, Practice determining strategies carefully, Train creativity with limited material, Practice concentration, dare to act and not be afraid of being wrong, Gluing tenuous interpersonal relationships, Train to respect others, Strengthen selfconcept, Train the soul of leadership, Practice being scientific, Practice making decisions and actions. 
Based on these benefits, it is clear that ice breaking can be an alternative to be used in learning. Learning is not monotonous and not bored for students. Especially very both used in the learning process of English which are usually impressed difficult for students.

\section{METHOD}

This research was conducted on VII grade students high school in Cimahi city, VII D class consisting of 32 female students. This study chose VII grade students because the age level of these students is usually students who are less interested in studying singular languages, especially English.

In this study, there are two types of data collected by researchers. The first is quantitative data, and the second is qualitative data. Quantitative data refers to the value of students taken in the results of the pretest and post-test. Qualitative data relates to events and changes that occur during class activities, including student behavior, class situations, class activities processes are examples of qualitative data. The researcher collected qualitative data using observation, field notes, recordings, questionnaires and interviews. Observation carefully observes and records events in class, occurring during the interaction of all participants in the course of learning in the classroom.

Observations is used in order to observe what is going on or what is happening in the observed context(Fraenkel and Wallen, 2008, cited in Apsari \& Yana, 2015 ). It can be combined with field notes, and recordings, including in terms of analyzing data, and collecting data. As Creswell (2012) in Yanto (2009) states that "Analyzing data in qualitative research requires understanding how to understand text and images, so that answers can be formed for all questions in research". According to Moleong (2011) in Ennser-Kananen \& Wang (2016) Qualitative research is research that is intended to understand about what is experienced by the subject of research such as behavior, motivation, actions and others by means of descriptions in the form of words and language, in a special context that is natural and with utilizing various natural methods.

In this study the author uses the case study method as his strategy. Case study method is a method based on the specificity of a particular problem or case. The case in question can be an individual or several individuals. As the opinion stated by Robert (2009) in Masud (2018) that "a single case study is a single respondent in a survey or a single subject in an experiment conducted".

This research was conducted in five meetings. In each meeting about 80 minutes to see the process of increasing students' interest and motivation in English lessons. That was done from February 2019.

\section{RESULTS AND DISCUSSION}

\section{Results}

This study aims to determine the effect of the application of the Ice breaking technique in the learning process of English to the learning outcomes of the sixth grade students of High School in Cimahi City. With the number of samples used obtained data from the results of pretest and post-test students and the results of data from the observation of the implementation of Ice breaking learning has increased. 
The study was conducted for five meetings. The first meeting was used to provide several spontaneous interviews in the classroom and pretest questions to measure students' English skills and the last meeting was used to conduct interviews and questionnaires and conduct posttests to find out the final results of increasing student interest in English. The form of pretest and post-test is multiple choice, during the learning process the researcher conducts observations by giving some field notes to capture what students are doing in the process of increasing students' learning motivation in the classroom.

The action steps and observations are shown in the table below:

Table 1 .Activity table

\begin{tabular}{cl}
\hline Meeting & \multicolumn{1}{c}{ Activities } \\
Meeting 1 & $\begin{array}{l}\text { In this first meeting the researchers told students to introduce themselves by } \\
\text { doing ice breaking singing "Hello How Are You?" and start to do a written } \\
\text { pretest along with the questionnaire on the final sheet. }\end{array}$ \\
Meeting 2 & $\begin{array}{l}\text { Students begin learning by praying and starting ice breaking or warming up } \\
\text { before discussing learning material. The ice breaking used is "Double O } \\
\text { Activity" }\end{array}$ \\
\hline Meeting 3 & $\begin{array}{l}\text { Researchers began to conduct material discussions together with ice breaking } \\
\text { or warming up. The students were divided into } 4 \text { groups, each group playing } \\
\text { the guess "who am I?" in front of the class alternately }\end{array}$ \\
\hline Meeting 4 & $\begin{array}{l}\text { Continuing the discussion at the previous meeting, the ice breaking that was } \\
\text { used before starting the lesson was "Pat the animal". }\end{array}$ \\
\hline Meeting 5 & $\begin{array}{l}\text { In this meeting the researcher conducted a post test with the same question, to } \\
\text { find out whether there was an increase after several meetings took place. }\end{array}$
\end{tabular}

The results of the table above will be explained through a description that is, starting from the pre-test consisting of 20 well-executed questions, even though some students score less than the minimum criteria. The minimum criteria must be 7.00 , but the average pretest of all students in the class is 5.25 . The score is considered very low for the minimum value that should be, plus the ability of students who are almost entirely late to understand the concept being taught.

The final score of students increased from the average pretest 5.25 to 8.20 in the first post test and the quality of students in the learning process increased. This can be seen from the attitudes and behavior shown by students during learning.

Table 2.Test score

\begin{tabular}{lcc}
\hline & Pre - Test & Post - Test \\
\hline Score minimum & 3 & 6 \\
\hline Score maximum & 7 & 9 \\
\hline Score average & 5.25 & 8.20
\end{tabular}


While the attitudes and behavior of students have increased as in the table below.

Table 3. Increased cognitive skills

\begin{tabular}{|c|c|c|}
\hline Point & First condition & improvement \\
\hline Activeness & $\begin{array}{l}\text { At the first meeting the } \\
\text { students were less active. Just } \\
\text { sit there shut up and pay } \\
\text { attention. There are even some } \\
\text { students who don't pay } \\
\text { attention, only focus on other } \\
\text { things. }\end{array}$ & $\begin{array}{l}\text { Students are more active here and there, and } \\
\text { pay attention to whoever is speaking in front } \\
\text { of the class. Frequently asked questions that } \\
\text { they don't know yet }\end{array}$ \\
\hline Knowledge & $\begin{array}{l}\text { It feels strange to learn English } \\
\text { in students because there is no } \\
\text { motivation to learn it. }\end{array}$ & $\begin{array}{l}\text { Initially only } 10 \% \text { of students who liked } \\
\text { English, through the learning process and the } \\
\text { addition of ice breaking before learning } \\
\text { students who liked English increased to } 50 \% \text {. } \\
\text { Students begin to say words in English }\end{array}$ \\
\hline
\end{tabular}

Students don't seem interested in the learning process. There are some students who don't get along with other students,

Enjoyment because there are gaps between them. The lack of cooperation between students in the class is seen when students with each other only care about their assignments.
Students' interest in learning English is increasing. More courage to speak in front of the class adds value to student attitudes in this matter. There is no need to wait for the teacher to point, some students have started voluntarily going to the front of the class

As shown in the table above there is an increase in value in the learning process, which exceeds the value of the required criteria. And there is also an increase in attitudes and behaviors that occur in students. Therefore, this research has found the final result, namely starting learning using ice breaking or warming up is proven to help students develop and increase their motivation and interests, both in test scores and cognitive values. The important thing that was obtained in this study was the change in students' attitudes towards English lessons that they initially feared were now a favorite subject and were very enthusiastic in starting their learning.

\section{Discussion}

During the meeting, researchers pay attention to the way students learn and accept warming up before starting learning. Students still feel confused to do ice breaking through guesses that 
have been explained, they still have to be given examples and guidance from the teacher to do each step. However, this does not reduce students' joy and enthusiasm for the lessons to be discussed.

The next meeting the researchers saw students increasingly enthusiastic in asking in the learning process, this made the classroom situation noisy because of the many enthusiastic students. Considering that the research conducted was to increase student motivation, it was seen at each meeting and at the final grade of students in the post-test.

\section{CONCLUSION}

The study was conducted in five meetings and further deepened ice breaking or warming up at the beginning of each meeting. From the results of the data it can be concluded that the ability of seventh grade students has increased. By using ice breaking when learning takes place can increase students' motivation and interest in English, this right is evident from the increase that occurred in this study.

This increase consists of: increasing the average score and increasing the value of student attitudes and behavior. The average pretest score is 5.25, and the post-test is 8.20 . Increased attitudes and behavior can be seen from the more pleasant activity, knowledge, and atmosphere of the class.

After the authors conducted the study, the authors concluded that ice breaking or warming up can increase students' motivation and interest in the learning process. And in this case study study the authors suggest that teachers can use ice breaking in class because it can motivate students to feel more enjoyable in the learning process and they will not feel bored quickly.

\section{ACKNOWLEDGMENTS}

Alhamdulillahirabbil'alamin, praise and thank you to Allah SWT, the Most Gracious, and Most Merciful. Praise God for the blessings given to the author so that can complete this work entitled "The Influence Of Ice Breaker To Students' Motivation In Teaching English" as a requirement to get a degree in English Language Education at Institute Keguruan dan Ilmu Pendidikan Siliwangi Bandung.

We want to express our sincere gratitude to the Siliwangi Bandung Teacher Training and Education Institute, thank you to Ms. Intan Satriani M.Pd as the mentor of the work, for guidance during this writing process. Thank you to our parents and our family for their continued support. Thanks to all classmates and those who have helped and motivated in completing this work. We always hopefully this creation will be useful for all readers.

\section{REFERENCES}

Apsari, Y., \& Yana, Y. (2015). Teachers'techniques And Problems In Teaching Reading. Jurnal Ilmiah P2M STKIP Siliwangi, 2(2), 217-233.

Dauyah, E., Abulyatama, U., \& Besar, A. (2018). No Title. 30(September), 196-209.

Dollard, J., Dollard, J., \& Miller, E. (n.d.). John dollard \& nael e miller. 1-8.

Ennser-Kananen, J., \& Wang, A. F. (2016). Journal of language teaching and research. Journal of Language Teaching and Research, 7(4), 625-634. Retrieved from http://www.academypublication.com/ojs/index.php/jltr/article/view/jltr0704625634/781

Masud, M. (2018). An Examination of Case Studies in Management Research: A Paradigmatic Bridge. International Journal of Social Science Studies, 6(3), 9. 
https://doi.org/10.11114/ijsss.v6i3.2971

Parmawati, A. (2018). The Study Correlation Between Reading Habit And Pronunciation Ability At The Second Grade Students Of Ikip Siliwangi. Eltin Journal, Journal Of English Language Teaching In Indonesia, 6(1), 46-52.

Perolehanngelarrmagisterrhumanioraa, D., Budiawann, O., \& Bidanggstudiilinguistikk, P. (2008). PengaruhhSikappBahasaadannnMotivasiiBelajarrBahasaaterhadapp PrestasiipadaaMataaPelajarannBahasaaIndonesiaadannBahasaa Inggrisss SiswaaSMAAse-BandarrLampungg Tesiss.

Yanto, D. (2009). Studi Kasus. Journal of Cleaner Production, 17(2), 283-296. https://doi.org/10.1016/j.jclepro.2008.06.005

Yeganehpour, P., \& Takkaç, M. (2016). Using Ice-Breakers in Improving Every Factor Which Considered in Testing Learners Speaking Ability. International Journal on New Trends in Education and Their, (January), 58-68. 